Rev. Adm. Saúde - Vol. 18, № 72, jul. - set. 2018

http://dx.doi.org/10.23973/ras.72.128

ARTIGO DE ATUALIZAÇÃO

\title{
A importância da comunicação no processo de liderança
}

The importance of communication in the leadership process

\author{
Rosineia Oliveira dos Santos ${ }^{1}$
}

1. Administradora de empresas, mestre em ciências humanas. Pesquisadora da Universidade de Santo Amaro, São Paulo SP

\section{RESUMO}

A comunicação é uma necessidade básica do homem social, ela é o canal pelo qual os padrões de vida, de cultura são transmitidos, em que se aprende a ser membro de uma determinada sociedade. Temos como objetivo neste artigo demonstrar por meio de exemplos de liderança durante o processo de comunicação que há dificuldades nesse caminho ao transmitir uma mensagem e também indicar pontos que são fundamentais para os lideres durante o processo. O problema de investigação é de que forma os lideres conseguirão demonstrar a sua comunicação durante o processo em que estarão no poder? Será que seu processo de comunicação dentro da organização é o mais indicado? A metodologia utilizada para esta pesquisa foi a bibliográfica, que permitiu o conhecimento de material relevante e comparando o que já foi publicado na internet em relação ao tema de outros autores, de modo que se possa delinear uma nova abordagem sobre o mesmo, chegando à conclusões que possam servir de base para pesquisas futuras. É necessário que as pessoas contribuam para o desenvolvimento da organização e o líder que tem papel diretamente ligado à sua equipe, poderá proporcionar as ferramentas necessárias para se atingir os objetivos de ambas as partes. As fontes consultadas nesta foram Bergamini (1990 e 1994), Pimenta (2000) e House (1971).

Palavras-chave: conhecimento, organização, liderança, gestão de pessoas. 


\begin{abstract}
Communication is a necessity of the social man, it is the channel by which the standards of life, of culture are transmitted, in which one learns to be a member of a certain society. The purpose of this article is to demonstrate through examples of leadership during the communication process that there are difficulties in this way when transmitting a message and indicate points that are fundamental for the leaders during the process. The research problem is how leaders will be able to demonstrate their communication during the process in which they will be in power? Is your communication process within the organization the right choice? The methodology used for this research was the bibliographical one, which allowed the knowledge of relevant material and comparing what was already published on the internet in relation to the theme of other authors, so that a new approach could be outlined, reaching the conclusions which may serve as a basis for future research. It is necessary for people to contribute to the development of the organization and the leader who has a role directly connected to their team can provide the necessary tools to achieve the objectives of both parties. The sources consulted in this one was Bergamini (1990 and 1994), Pimenta (2000) and House (1971).
\end{abstract}

Keywords: knowledge, organization, leadership, people management.

\title{
INTRODUÇÃO
}

Comunicar vem do latim, communicare, tornar comum. Comunicação compõe o processo básico para a prática das relações humanas, assim como para o desenvolvimento da personalidade individual e do perfil coletivo. Segundo Chiavenato (2000), é a troca de informações entre indivíduos. Significa tornar comum uma mensagem ou informação.

Ao conceito de Scanlan (1979, p. 372), "a comunicação pode ser definida simplesmente como o processo de se passar informações e entendimentos de uma pessoa para outra".

Comunicar, neste sentido, é o processo de transmitir a informação e compreensão de uma pessoa para outra. Se não houver esta compreensão, não ocorre a comunicação. Se uma pessoa transmite uma mensagem e esta não for compreendida a comunicação não se efetivou. 
$O$ ato de estar face a face com a pessoa também desenvolve uma parceria e confiabilidade únicas que sempre farão parte da rotina. O subordinado passa a confiar inteiramente em seu líder, mas se passar a presenciar situações de guerra entre as áreas, automaticamente o cenário será alterado. Quem antes te admirava por suas atitudes, agora não te reconhece mais. Muitas vezes 0 gestor trata o funcionário de uma forma e depois de outra, mudando totalmente suas ações.

Nosso objetivo foi demonstrar por meio de exemplos do processo de comunicação e liderança que o saber ouvir é entender a dificuldade que uma pessoa tem ao transmitir uma mensagem, buscando conscientizar o líder e liderado que se deve perguntar exaustivamente até ter a compreensão do todo e analisar se o processo de comunicação utilizado pela organização é o mais claro e objetivo para conseguir atingir seus colaboradores e também estudar a comunicação e indicar os pontos que são fundamentais para os lideres durante o processo.

Como problema de pesquisa sabemos que a comunicação é o processo de troca de informações entre duas ou mais pessoas. Desde os tempos mais remotos, a necessidade de nos comunicar é uma questão de sobrevivência, ou seja, no mundo dos negócios não é diferente. A necessidade de tornar os funcionários influentes, integrados e informados do que acontece na empresa, fazendo-os sentir parte dela, fez surgir a comunicação, considerada hoje como algo imprescindível às organizações, merecendo, cada vez mais, maior atenção. Desta forma, os lideres conseguirão demonstrar a sua comunicação durante o processo em que estarão na liderança? Será que seu processo de comunicação dentro da organização é o mais indicado? Seus colaboradores o entenderão? Quando transmitirmos uma orientação, um pedido, ou uma ordem, nem toda parte da informação é compreendida perfeitamente, portanto, devese ir direto ao assunto.

A comunicação do dia a dia e a comunicação organizacional têm um código para formular uma mensagem e enviá-la na forma de sinal (como ondas sonoras, letras impressas, símbolos), por meio de um canal (ar, fios, papel) a um receptor da mensagem que a decodifica e interpreta o seu significado. Já na comunicação pessoal - conversação - a linguagem funciona como código e é reforçado por elementos de comunicação não verbal (como gestos, sinais, símbolos). A comunicação interpessoal também se pode dar a distância, por meio da escrita, telefone ou internet como meio de transmitir as mensagens.

No desenvolvimento do trabalho foram incluídas pesquisas bibliográficas, que permitiu comparar o que já foi publicado em relação ao tema e analisar outros autores que abordam a temática, de modo que se possa delinear uma nova abordagem sobre o mesmo, chegando a conclusões que possam servir de embasamento para pesquisas futuras. A metodologia utilizada será a demonstração de uma nova forma de tratamento entre líder e colaborador, principalmente por meio de diálogos e feedbacks constantes visando o desenvolvimento do colaborador e consequentemente o da própria organização. De acordo com Gil (2002) é sabido que toda e qualquer classificação se faz mediante algum critério com base em objetivos gerais, 
sendo que ela pode se classificar em três grandes grupos: exploratórias, descritivas e explicativas.

A metodologia utilizada para a pesquisa acadêmica foi de Gil (2002) onde informa que: Pesquisa é um processo formal e sistêmico de desenvolvimento do método científico, que tem como objetivo descobrir respostas para problemas mediante o emprego de procedimentos científicos.

\section{COMUNICAÇÃO E SEUS DIFERENTES CONCEITOS}

A comunicação segundo Chiavenato (2003) é importante no relacionamento entre as pessoas e na explicação aos participantes das razões das orientações tomadas. Os subordinados devem receber um fluxo de comunicação capaz de suprir-lhes as necessidades. Por outro lado, os superiores devem receber dos subordinados um fluxo de comunicações capaz de lhes fornecer uma ideia adequada do que está acontecendo. A comunicação organizacional em duas vias (descendente e ascendente) é importante, pois:

A pessoa trabalha melhor quando conhece os padrões do seu trabalho; a organização opera mais eficientemente quando a pessoa e seu chefe têm um entendimento comum das suas responsabilidades e padrões de desempenho que a empresa espera obter deles; cada pessoa pode ser auxiliada a dar a máxima contribuição à organização e a utilizar ao máximo as suas habilidades e capacidades (CHIAVENATO, 2003, p. 135).

A comunicação é um dos processos fundamentais da gerência e do comportamento organizacional. Sob um ponto de vista organizacional, a comunicação pode ser analisada em termos de três funções amplas de acordo com Chiavenato (2003, p.129):

- Produção e controle: comunicação dirigida à realização do trabalho e ao cumprimento de objetivos de produção da organização, tais como controle a qualidade;

- Inovação: mensagens sobre novas ideias e mudanças de procedimentos que ajudam a firma a se adaptar e responder ao seu meio ambiente;

- Socialização e manutenção: comunicação voltada para os meios de realização do trabalho e não o trabalho em si, e para o envolvimento pessoal, as relações interpessoais e a motivação das pessoas na empresa.

Para Ruggiero (2013), a qualidade da comunicação é derivada de alguns pontos considerados de suma importância:

- Prioridade à comunicação - qualidade e timing da comunicação assegurando sintonia de energia e recursos de todos com os objetivos maiores da empresa; 
- Abertura da alta direção - disposição da cúpula de abrir informações essenciais garantindo insumos básicos a todos os colaboradores;

- Processo de busca - pro atividade de cada colaborador em busca as informações que precisa para realizar bem o seu trabalho;

- Autenticidade - verdade acima de tudo, ausência de "jogos de faz de conta" e autenticidade no relacionamento entre os colaboradores assegurando eficácia da comunicação e do trabalho em times;

- Foco em aprendizagem - garantia de efetiva aprendizagem do que é comunicado, otimizando o processo de comunicação;

- Individualização - consideração às diferenças individuais (evitando estereotipo e generalizações) assegurando melhor sintonia e qualidade de relacionamento na empresa;

- Competências de base - desenvolvimento de competências básicas em comunicação (ouvir, expressão oral e escrita, habilidades interpessoais) assegurando qualidade das relações internas;

- Velocidade - rapidez na comunicação dentro da empresa potencializando sua qualidade e nível de contribuição aos objetivos maiores;

- Adequação tecnológica - equilíbrio entre tecnologia e alto contato humano assegurando evolução da qualidade da comunicação e potencializando a força do grupo.

Cada uma dessas funções é importante para uma organização administrada de maneira eficiente e eficaz. Segundo Chiavenato (2001, p. 166) "ao enfatizar a criação de grupos e não o comportamento individual, a Teoria das Relações Humanas trata a comunicação como fenômeno social". Nesse mesmo sentido, informa Chiavenato (2001) o processo de comunicação é composto de três etapas subdivididas: Emissor: é a pessoa que pretende comunicar uma mensagem, pode ser chamada de fonte ou de origem. Significado: corresponde a ideia, ao conceito que o emissor deseja comunicar. Codificador: é constituído pelo mecanismo vocal para decifrar a mensagem.

Embora o processo básico da comunicação e os modos, barreiras e habilidades de comunicação interpessoal evidentemente influenciam esta forma de comunicação, a chave para a comunicação organizacional é a disposição e a estrutura de como a organização é dirigida às pessoas especificas e grupos que dela precisam para fins de trabalho, solução de problemas, controle ou tomada de decisão (MOREIRA, 2006, p. 33). 
Para compreender como a informação é canalizada nas organizações e como ela realmente flui, é preciso examinar tanto as redes de formas de comunicação como os canais mais informais da comunicação nas organizações, por meio de rumores e fofocas (PIMENTA, 2000). Vejamos alguns tipos de comunicação de acordo com Pimenta (2000, p. 35):

- Mensagem: é a ideia em que o emissor deseja comunicar.

- Canal: também chamado de veículo, é o espaço situado entre o emissor e o receptor.

- Ruído: é a perturbação dentro do processo de comunicação.

- Receptor: é a etapa que recebe a mensagem, a quem é destinada.

- Decodificador: é estabelecido pelo mecanismo auditivo para decifrar a mensagem, para que o receptor a compreenda.

- Compreensão: é o entendimento da mensagem pelo receptor.

- Regulamentação: o receptor confirmar a mensagem recebida do emissor representa a volta da mensagem enviada pelo emissor (feedback).

Segundo Moran (1998) quase toda a comunicação verbal é realizada por escrito e devidamente documentada por meio de protocolo, mas é composta pela palavra e compõe em oral e escrita.

- Comunicação verbal: quase toda a comunicação verbal é realizada por escrito e devidamente documentada por meio de protocolo, mas é composta pela palavra.

- Comunicação oral: são as ordens, pedidos, conversas, debates, discussões.

- Comunicação escrita: são as cartas, telegramas, bilhetinhos, letreiros, cartazes, livros, folhetos, jornais, revista.

- Comunicação não-verbal: por meio desta comunicação não verbal ocorre a troca de sinais: olhar, gesto, postura, mímica.

- Comunicação por mímica: são os gestos das mãos, do corpo, da face, as caretas.

- Comunicação pelo olhar: as pessoas costumam se entender pelo olhar.

- Comunicação pela postura: o modo como nos sentamos, o corpo inclinado para trás ou para frente, até mesmo a posição dos pés. Tudo isso na maioria das vezes é o nosso subconsciente transmitindo uma mensagem. 
- Comunicação por gestos: pode ser voluntária, como um beijo ou um cumprimento. Mas também pode ser involuntária, como por exemplo, mãos que não param de rabiscar ou de mexer em algo. Isso é sinal de tensão e, ou nervosismo.

A maneira como um grupo ou organização é estruturada, em última análise, $\mathrm{e}$ que determina a acessibilidade e a facilidade com que os seus integrantes podem se comunicar entre si.

\section{CANAIS DE COMUNICAÇÃO}

A comunicação de acordo com Gessner (2013) dentro das empresas deve ser clara e precisa, necessita de um organograma bem planejado, para que a mensagem não chegue distorcida. A seguir veremos os modelos de canais de comunicação que ocorrem dentro de empresas:

- Canais verticais: podem ser descendentes (de cima para baixo) e referem-se à comunicação entre o superior e os subordinados, veiculando ordens ou instruções. Podem ser ascendentes (de baixo para cima) e referem-se à comunicação entre o subordinado e o supervisor, veiculando informações a respeito do trabalho executado.

- Canais horizontais: refere-se às comunicações laterais entre dois órgãos (dois departamentos, duas seções) ou dois cargos (dois gerentes) no mesmo nível hierárquico.

Todo profissional de $\mathrm{RH}$ atuante sabe que, antes de se voltar para qualquer das direções já mencionadas, necessita desenvolver sua capacidade de receber e enviar mensagens, capacidade essa que se traduz, principalmente, no cultivo das habilidades de saber ouvir (GESSNER, 2013).

As diversas formas de estrutura organizacional, com suas vantagens e desvantagens, bem como as redes de comunicação, formais e informais, que influenciam a comunicação dentro das organizações serão expostas a seguir.

De acordo com Ribeiro (2008, p. 14) "em um ambiente de trabalho diversificado, as barreiras culturais e de linguagem, por vezes, tornam-se uma preocupação número 1 (um) para os funcionários e gerentes".

As competências linguísticas, portanto, são importantes quando um supervisor ou gerente explica como executar uma tarefa. Se um empregado não completar o trabalho conforme o esperado, ele interrompe produção em outras áreas da organização. Respeitando as crenças, valores de outras pessoas, diferença de idade também pode afetar a comunicação porque diferentes grupos etários têm expectativas diferentes, hábitos, comportamentos e botões motivacionais todos esses mecanismos são importante para a comunicação eficaz. (RIBEIRO, 2008).

Thayer (1972) informa que para que uma organização seja bem-sucedida, eles devem ter uma comunicação eficaz entre os colegas de trabalho dentro da 
organização. Informa ainda que se está comunicação de rosto a face ou por meio de técnicas mediadas pelos computadores, tais como e-mail ou chat, é extremamente importante que todos os colaboradores estejam cientes de que tarefas estão sendo trabalhadas, que progresso está sendo feito e que o objetivo final é. Comunicação eficaz sobre estes temas entre colegas de trabalho em uma organização leva à alocação mais eficiente dos recursos humanos, e por sua vez a produtividade, maior.

Uma organização mais flexível, do tipo matricial, já pode determinar, da mesma forma, o uso de outros tipos de fluxo de informações e esforço de comunicação. Mesmo assim, em cada uma das formas organizacionais, as redes informais de comunicação também influenciam o fluxo de informações e os padrões de comunicação (THAYER, 1972, p.27).

Comunicar é a ação de falar alguma informação ou fato a alguém. Segundo Jesus (2011), a comunicação tem três estilos básicos: agressivo, passivo e assertivo. E cada situação exige um estilo diferente.

O grupo alvo deve compreender a mensagem específica que o transmissor deseja passar. Somente desta forma que conseguiremos a resposta correta para a nossa indagação. Apenas se tivermos uma conversa clara e concisa é que melhoraremos a comunicação. Comunicação é convivência, deixar algo comunicado quer dizer que foi consentido pelas outras pessoas que convivem neste meio. O grande objetivo da comunicação nada mais é do que fazer com que as pessoas se entendam e se compreendam mutuamente. A comunicação é uma resposta de um estímulo interno ou externo. Esta resposta ao estímulo forma na mente uma ideia ou imagem, com seu símbolo representativo, que conhecemos por experiência anterior: o nome. O sentimento resultante desta experiência completa o processo da comunicação humana.

Comunicação é o processo por meio do qual os administradores realizam suas funções de planejamento, organização, liderança e controle. A comunicação é uma atividade à qual os administradores dedicam uma enorme proporção do seu tempo (STONER, 1999, p. 388).

Kotter (1978) definiu comunicação como um processo que consiste em um emissor transmitindo uma mensagem, por meio de um meio, para um receptor que reage. (emissor- mensagem - receptor). Este modelo indica que existem três elementos essenciais na comunicação, na falta de um deles não pode ocorrer comunicação. Podemos mandar uma mensagem, por exemplo, mas ela não é ouvida ou recebida por alguém, não ocorrendo, portanto, qualquer comunicação. Devemos considerar ainda, que nem sempre a informação enviada pelo transmissor é compreendida de forma consistente pelo receptor. Isto porque toda informação é interpretada pela subjetividade do receptor, que a modifica segundo parâmetros pessoais e intrínsecos.

Se um indivíduo fala e ninguém ouve, o processo da comunicação humana não se completou: há apenas a expressão, ou seja, o primeiro passo do processo. Falta à expressão o essencial: a transmissão, que será definida sempre por dois elementos: o transmissor e o receptor. 
Para Penteado (1993, p. 23) a comunicação humana compreende uma variedade de formas, através das quais as pessoas transmitem e recebem ideias, impressões e imagens de toda ordem. Alguns desses símbolos, embora compreensíveis, jamais conseguem ser expressados por palavras.

Uris (1972) comenta sobre a auto comunicação e considera a psicanálise de Freud como esforço terapêutico no sentido de fazer que a criatura humana estabeleça comunicação com ela própria. A comunicação humana exige a participação de pelo menos duas pessoas. A auto comunicação faz-se dialética na prática, mediante o artifício de considerar, dentro de uma única pessoa, dois seres distintos.

Para Genelot (2001) classificamos como mensagem o que o emissor transmite e o receptor recebe. A mensagem é o elo dos dois pontos do circuito. $E$ o mesmo autor (2001) informa também que a interpretação precisa coincidir com a emissão e na recepção, a fim de que o significado seja o mesmo: do emissor para o receptor e do receptor para o emissor. Ou seja, podemos definir que na verdade não são necessárias apenas duas ferramentas e sim, três: o transmissor, o receptor e a mensagem.

Sem estes três, não estará completa a comunicação humana. Toda mensagem deve ser significativa para ambos, o que emite e o que recebe. Compreende-se que a comunicação humana é formada por sons, gestos, sinais, símbolos, etc.

\section{LIDERANÇA E SEUS MODELOS CONCEITUAIS NA GESTÃO ORGANIZACIONAL}

Segundo Bergamini (1994, p. 15) "a liderança está ligada a um fenômeno grupal, ou seja, precisa envolver duas ou mais pessoas". Declara ainda Bergamini (1994) que a liderança é um processo de influência. Podemos dizer que esta influência ocorre justamente por um objetivo em comum. Embora o líder seja quem geralmente inicia as ações, os seguidores devem estar dispostos a colaborar visto que a liderança exerce determinado efeito sobre o comportamento dos membros de determinado grupo.

O líder é visto como alguém que traz algum benefício não só ao grupo em geral, como a cada membro em particular, devido ao envolvimento nesta relação.

Liderar é ser capaz de administrar o sentido que as pessoas dão àquilo que estão fazendo. Essa administração do sentido implica o conhecimento e domínio das características da cultura da organização (BERGAMINI, 1994).

Bergamini (1994, p. 47) também cita que:

ao mesmo tempo em que liderar exige também o conhecimento do sentido que cada um dá à atividade que desempenha. Infelizmente não somente no Brasil, alguns programas de treinamento foram desenvolvidos a fim de criar e formar verdadeiros bons líderes. Grande parte destes programas depois de aplicados na prática foi ineficaz visto 
que, de fato, não conseguiriam modificar o comportamento destes chefes de empresa. Ao longo do tempo buscaram-se encontrar parâmetros, motivações, fontes de poder e características extrínsecas ao processo de liderança que fossem capazes de explicar qual seria a variável mais importante para se conseguir tornar o líder mais notável em suas atividades de influenciar seus seguidores.

Segundo Bergamini (1994, p. 28) "os dois primeiros tipos de investigação mais simples a respeito da eficácia do líder estão contidos nas teorias dos traços e dos estilos, que enfatiza especialmente as qualidades pessoais do líder". Tal tendência de estudo ficou assim conhecida porque seus pesquisadores propunham como ponto de partida que os líderes deveriam possuir certas características de personalidade especiais que seriam basicamente as principais facilitadoras no desempenho no papel da liderança.

Desta forma, os líderes passaram a ser entendidos como seres diferentes das demais pessoas pelo fato de possuírem alguns traços de personalidade considerados como profundos, responsáveis não só por fazê-los emergir como tal como também por mantê-los em suas posições. Na proposta adotada pela teoria dos traços são enfatizadas, portanto, qualidades pessoais do líder. Isso permite concluir que já nascem como tal, não havendo a probabilidade de criá-los posteriormente por meio do uso de técnicas de desenvolvimento pessoal (BERGAMINI, 1994, p. 29).

enfoque dos traços predominou até a década de quarenta, tendo como grandes contribuintes para o seu sucesso as pesquisas desenvolvidas pelos testes psicológicos muito incrementados a partir de 1920 até 1950. (BERGAMINI, 1994).

A professora Cecília W. Bergamini e o professor Roberto Coda traduziram um artigo do então professor PHD Laurent Lapierre, em que informam na Revista de administração de empresas em artigo publicado em 1989 que mesmo sendo em outra década o assunto permanece relevante e que muitos profissionais envolvidos com a alta administração atuam sob uma falsa compreensão da natureza do trabalho executivo, já que não entendem com clareza que dirigir uma empresa não é exatamente sinônimo de liderança. É possível reconhecer a liderança quando com ela nos deparamos, mas sua verdadeira natureza está escondida nos habituais falsos conceitos sobre organização, natureza humana e tudo aquilo que representa a essência do trabalho do executivo.

Neste mesmo artigo Bergamini; Coda (1989) informam que a personalidade dos indivíduos em cargos de direção tem uma influência inegável sobre a forma de administrar empresas. Uma pessoa em posição de diretor não é totalmente um líder ou totalmente um administrador. Um administrador é caracterizado como uma pessoa que dirige a empresa. Nem sempre o diretor formou-se em administração de empresas, mas recebe o cargo de diretor, procurador ou administrador devido a grande experiência em sua vida profissional.

Segundo House (1971, p. 324), 
a função motivacional do líder resiste nas crescentes recompensas pessoais dos subordinados no sentido da chegada aos objetivos do trabalho, fazendo com que o caminho para essas recompensas se torne mais fácil de ser percorrido ao deixá-lo mais evidente, reduzindo os bloqueios do percurso e as armadilhas bem como aumentando as oportunidades de satisfação pessoal em curso. Os líderes eficazes devem assumir três tipos de conduta que terão a propriedade de influenciar a produtividade de seus subordinados. Em primeiro lugar o líder precisa mostrar consideração e oferecer apoio. A seguir, deve ser capaz de estruturar com clareza a situação, mostrando caminhos que podem ser seguidos para se chegar aos objetivos almejados. Finalmente, espera-se que o líder venha facilitar a chegada às recompensas esperadas e valorizadas, uma vez que tenha evidenciado o desempenho esperado.

$\mathrm{Na}$ tentativa de enriquecer sua teoria, House (1971) distingue quatro tipos de comportamentos em liderança:

- Liderança diretiva é quando o comportamento do líder se caracteriza por estipular aquilo que se espera do subordinado e são dadas orientações específicas de como chegar a isso, demarcando ritmos e padrões de desempenho.

- Liderança de apoio é quando o comportamento do líder deixa evidente sua preocupação pelo bem-estar do subordinado.

- Liderança participativa é quando o comportamento do líder é típico de consulta e são pedidas sugestões consideradas como importantes no processo de tomada de decisões.

- Líder orientado para a realização é classificado na medida em que se dedica à colocação de objetivos desafiantes, evidenciando confiança na responsabilidade e esforço por parte dos subordinados.

De acordo com este modelo, de um lado há a qualidade das decisões e do outro a aceitação dessas decisões por parte dos subordinados. A preocupação seria em sugerir como as decisões devem ser tomadas e implementadas para que se possa atingir a produtividade em um ambiente no qual predomine um clima onde haja sentimentos de satisfação.

Segundo Sugo (2006, p. 21):

Ser líder significa ser uma pessoa a serviço da outra, tendo como satisfação pessoal à satisfação dos companheiros, vendo no crescimento e progresso dos seus seguidores o seu próprio progresso e crescimento e, no bem-estar de cada um, o seu próprio bem-estar. É evidente dizer que o crescimento do grupo ou da equipe desencadeará no crescimento do seu líder. 
Informa ainda, Sugo (2006) que para o líder ser responsivo e diretivo é necessário saber comunicar-se, quando se orienta o nível de comunicação é um. Quando se ensina o nível de é outro. Quando se interpreta pessoas é outro. Pode-se dizer que a forma que o líder deve colocar em prática é a fala e a audição.

\section{MOTIVAÇÃO E FEEDBACK: SUA NECESSIDADE NAS ORGANIZAÇÕES}

Motivação é a missão mais árdua do líder, não basta apenas influenciar as pessoas para obter resultados é necessário motivá-las para que façam o que deve der feito. É um desejo interior de realizar algo que as leva à ação.

Segundo Ervilha (2008) o líder precisa trabalhar a motivação que se encontra em um nível superior aos das necessidades básicas, iniciando pelas sociais a formação de equipes, possibilitando o convívio com outros vizinhos, criando um ambiente de afiliação, companheirismo, cooperação e espírito de corporação. Salienta ainda Ervilha (2008) que está é a grande habilidade do líder, encontrar o equilíbrio entre os participantes de uma equipe e ao mesmo tempo desafiálos para que sejam competitivos. Não consegue motivar sem conhecer seu liderado. Cada pessoa tem sua própria motivação. Por isso é que não se consegue motivar as pessoas, e sim mostrar a elas como podem conseguir o que querem e, desta forma, elas irão se automotivar para atingir seu objetivo.

Ser líder é ter atitudes sempre positivas e ser decisivo em cada ação. É tomar decisões e correr riscos, trabalhando o dobro se necessário. É ter habilidades de se relacionar e comunicar-se com seus liderados claramente. O líder deve sempre influenciar pessoas e dirigi-las para os seus objetivos. Ele sabe tratar os liderados como vencedores e valorizá-los quando atingem um resultado fora do comum; sabe incentivá-los a crescer como profissionais e como pessoas.

De acordo com Gaudêncio (2007) o líder desencoraja as pessoas interrompendo-as, reprimindo ou não levando em conta o que elas têm a dizer. Olhar e escutar são apenas duas partes da liderança eficiente. Você deve prestar atenção a todo o momento alertá-los sobre o não bom relacionamento entre eles. Uma forma de fazê-lo é expressando tudo o que vê de forma profissional. Tenha diálogo com seus subordinados, pois sempre que precisar terá as portas abertas para expor seus sentimentos. E continua Gaudêncio (2007, p. 70) "se escuta ativamente quando limpa a mente e participa de tudo o que a outra pessoa está dizendo, sem desviar a atenção para si mesmo e seus problemas pessoais e organizacionais". Demonstrar interesse fazendo perguntas e se interessando pelo assunto do outro, acenar com a cabeça e pedir que a outra pessoa conte detalhes das coisas faz com que você encoraje o outro a falar o que pensa e o que precisa transmitir para você neste momento de troca de informações.

Segundo Bernardinho (2006, p. 114-115): 
Ser líder é dar o exemplo para que outros saibam como se faz e se esforcem para repetir a tarefa no mesmo nível ou ainda melhor. Essa é a única liderança que se sustenta com o tempo. Nada do que você diz influencia mais as pessoas do que aquilo que você faz. Liderar é inspirar e influenciar pessoas a fazerem a coisa certa, de preferência entusiasticamente e visando ao objetivo comum. Afinal, uma equipe precisa de líderes no dia a dia que todos olhem como referência. São aqueles que ajudam o treinador, ou gestor, a conduzir seu time (ou projeto) pela estrada do planejamento até alcançar a meta almejada.

Bernardinho (2006) informa ainda que saber o que se passa dentro e fora do grupo, ajuda os membros da equipe a se relacionarem com as metas e objetivos da organização, esclarecendo expectativas em relação ao que devem fazer e a entender as necessidades ou exigências da organização como um todo. Dar à sua equipe a informação que você recebe em reuniões gerenciais, por exemplo, possibilita que seus membros usem esta informação para se tornarem mais bem-sucedidos. Normalmente, a equipe não tem outro canal para receber esta informação, a não ser aquele que você pode fornecer enquanto líder.

Segundo Bernardinho (2006, p. 115-116), "a motivação baseia-se em dois pilares: o primeiro deles é a necessidade. Se você precisa, vai "correr atrás" e se dedicar. O segundo é a paixão. Se você gosta, ama o que faz, vai querer melhorar sempre". Pode-se observar que estes conceitos tratam a motivação como sendo algo pessoal e que parte do interior das pessoas. Para se trabalhar em equipe, é necessária uma comunicação franca, honesta e direta; mas para isso é preciso muito esforço para conseguir este tipo de comunicação. Adotando todas estas formas, possibilitará a criação da comunicação eficaz que procuramos.

Segundo Bergamini (1990, p. 49):

Pode-se dizer que ninguém jamais conseguirá motivar ninguém. São as necessidades que estão dentro das pessoas e não os fatores que as satisfazem aquilo que deve ser considerado como fonte de sinergia motivacional. Cada pessoa tem sua personalidade estruturada de maneira particular, apresentando, consequentemente, um correspondente tipo de comportamento motivacional que Ihe é próprio, diferente das demais.

Chiavenato (1999) argumenta que a motivação está contida dentro das próprias pessoas e pode ser amplamente influenciada por fontes externas ao indivíduo ou pelo seu próprio trabalho na empresa.

Outros autores citam que a motivação está dentro de cada um. Vergara (1999), por exemplo, defende que a motivação é intrínseca, também não podemos dizer que motivamos os outros a isso ou aquilo. Ninguém motiva ninguém. Nós é que nos motivamos, ou não.

Silva; Rodrigues (2007, p. 09) reforçam essa teoria quando citam que: 
A motivação é um fenômeno que depende de numerosos fatores para existir, dentre eles, o cargo em si, ou seja, a tarefa que o indivíduo executa, as características individuais e, por último, os resultados que este trabalho pode oferecer. Portanto, a motivação é uma força que se encontra no interior de cada pessoa, estando geralmente ligada a um desejo. Dessa forma, suas fontes de energia estão dentro de cada ser humano.

Motivação seria sinônimo de necessidade. Como então saber o que fazer para motivar cada uma delas? Como generalizar formas de motivação para indivíduos que são, por essência e definição, diferentes? Aqui encontramos a origem da afirmação de que não é possível motivar diretamente ninguém, uma vez que a real motivação é intrínseca tanto em relação ao trabalho, quanto à própria pessoa que o executa.

A liderança é um processo ativo e não passivo. São pioneiras, pessoas dispostas a partir para o desconhecido. São pessoas dispostas a assumir riscos, inovar e experimentar novas coisas para melhoras as maneiras de fazêlas.

Segundo Bowditch; Buono (2006) os líderes despendem esforços consideráveis contemplando o horizonte do tempo, imaginando como serão as coisas quando eles tiverem chegado aos seus destinos finais. Podemos dizer que é caracterizado como finalidade, missão ou meta. Existe um desejo de fazer algo acontecer, de mudar a maneira em que estão as coisas, de criar algo que ninguém tenha criado antes. Os líderes veem como serão os resultados lá na frente e esta imagem os impulsiona para diante. Porém, as visões vistas somente pelo líder são insuficientes para criar um movimento organizado ou uma mudança significativa numa empresa. Uma pessoa sem seguidores não é um líder e, pessoas não s tornam seguidores até que aceitem uma visão como sendo delas próprias, ou seja, que esteja de acordo com o que elas também pensam e veem para a organização.

Lacombe; Heilborn (2008, p. 34):

Declara que os líderes conseguem que os outros comprem seus sonhos, mostrando-Ihes como todos serão servidos por uma finalidade comum. As pessoas precisam acreditar em suas palavras e acreditar que você compreende as necessidades e leva em conta seus interesses. Apenas sabendo de suas esperanças, aspirações, visões e valores é que o líder será capaz de recrutar apoio. Os líderes exemplares recrutam o apoio e a assistência de todos aqueles que devem fazer o projeto funcionar. Eles envolvem de algum modo, aqueles que devem viver com os resultados e tornam possíveis, para outros, efetuar um bom trabalho. Eles encorajam a colaboração, montam equipes e delegam autoridades a outras pessoas. Eles capacitam os outros para agir. Eles devem dirigir os projetos ao longo do curso, medir o desempenho, levantar fundos e efetuar ações corretivas. Quando aprendida esta lição, os líderes serão capazes de discorrer com orgulho a respeito de como o trabalho em equipe e a colaboração de todos do grupo são essenciais. 
Bernardinho (2006) informa nesta mesma linha de pensamento que o líder precisa modelar o caminho para os seus seguidores e deixar a diretoria e executivos da empresa sempre a par de todos os passos galgados por sua equipe, sempre alinhando com os objetivos da organização.

Independentemente do cargo, ele te dá autoridade, mas o seu comportamento que lhe dará respeito. Os seus subordinados farão sempre a mesma pergunta: Meu líder pratica tudo aquilo que prega? Os líderes só conseguirão modelar este caminho se houver planejamento e liderança por exemplo.

As pessoas não iniciam seu trabalho de cada dia com vontade de perder. É necessário o líder fazer sua parte e mostrar que cada um de seus subordinados pode vencer.

\section{HIERARQUIA DAS NECESSIDADES DE MASLOW NO MODELO MOTIVACIONAL}

Um dos modelos mais conhecidos e atraentes da motivação é a hierarquia das necessidades de Abraham H. Maslow. Defendia Maslow que as necessidades subjacentes a toda motivação humana poderiam ser organizadas numa hierarquia de cinco níveis básicos. A teoria propunha que as necessidades de nível mais baixo de um indivíduo precisavam estar satisfeitas antes que ele pudesse se interessar pelas de nível superior (MASLOW, 1973). Dentre elas podemos classificá-las como: Necessidades fisiológicas; Necessidades de segurança; Necessidades sociais; Necessidades do ego ou autoestima; Necessidade de realização pessoal.

A necessidade fisiológica (respirar, saciar sede e fome) é de importância primária. Quando as necessidades de convivência forem satisfeitas, a pessoa passará a se preocupar com segurança e abrigo. Assim que a sensação de segurança e ordem estiver completa, automaticamente as pessoas passarão a desenvolver desejos de afiliação ou relacionamento interpessoal. Enxergaremos então, o desejo das pessoas de criar laços interpessoais de amizade e afeto (MASLOW, 1973).

Depois que as necessidades básicas de sobrevivência e segurança tiverem sido satisfeitas, a oportunidade de participar de interações sociais se torna importante. Quando esta necessidade for satisfeita, as pessoas experimentarão a necessidade de sentir a estima pessoal, o reconhecimento (especialmente por aqueles que sejam importantes em suas vidas) e prestígio, bem como satisfazer as necessidades do ego, orientadas para a realização, sucesso e um grau de autonomia ou independência.

O estágio final da hierarquia de Maslow (1973) frisou a continuidade do autodesenvolvimento, a obtenção da plenitude do potencial do indivíduo como ser humano. Embora isso seja um tanto quanto arbitrário, Maslow concluiu que apenas dez por cento da população chega a atingir a realização pessoal. 
O principal valor desta abordagem é o reconhecimento e a identificação das necessidades individuais, com o propósito de motivar o comportamento. Apelando às necessidades insatisfeitas dos subordinados, os gerentes poderiam tentar influenciar o comportamento deles. Naturalmente pessoas diferentes estarão em pontos diferentes e mesmas pessoas podem estar em diferentes níveis. Muitas pessoas conseguirão satisfazer suas necessidades de nível mais alto fora do loca de trabalho.

Neste sentido, explica Bowditch; Buono (2006) que a teoria de Maslow enfatiza uma abordagem contingencial à motivação, sob o ponto de vista que os gerentes e as organizações devem ser flexíveis e capazes de adaptar incentivos sob medida para cada colaborador.

Para aumentar a totalidade do potencial da motivação, os gerentes precisam ser capazes de relacionar as necessidades dos funcionários envolvidos, e não apenas as suas próprias necessidades e suposições.

Foram identificados diversos modelos motivacionais durante os estudos, talvez a melhor forma de proceder seja ao invés de interpretar essas teorias como regras universais que expliquem exatamente o comportamento em todos os casos, considerar os modelos motivacionais como teorias intermediárias: não tão ambiciosas nem tão abrangentes como modelos universais, porém ainda úteis para se considerar como motivar pessoas de diversas maneiras.

Uma abordagem para a criação de uma teoria intermediária da motivação como essa é agrupar as pessoas segundo as formas em que elas são motivadas.

Comportamentos de afastamento como rotatividade e absenteísmo podem ser bem analisados pelas teorias do reforço, da equidade e da expectativa. Se uma pessoa pede demissão, a decisão pode ser explicada por recompensas inadequadas (teoria do reforço); recompensa desigual, se comparada à de outras pessoas que executam serviços semelhantes (teoria da equidade); ou pouca probabilidade de atingir as metas ou valências esperadas (teoria da expectativa). Por outro lado, a teoria das necessidades e do estabelecimento de metas não parece explicar comportamentos de afastamentos tão bem. (SPECTOR, 2002, p. 205).

É necessário descobrir quais são os aspectos da motivação que faltam para certa situação e, trabalhar no desenvolvimento deles. Dependendo das circunstâncias, isso pode incluir atos como: tornar os cargos mais desafiantes, melhorar os sistemas de recompensas intrínsecas e extrínsecas, estabelecerem metas mais difíceis ou mais abrangentes, ajudar as pessoas a atingirem suas metas, remover barreiras que possam impedir as pessoas de atingirem seus objetivos e reforçar os comportamentos apropriados, enquanto se desencorajam outros.

Para se definir organização têm-se diferentes conceitos, dentre eles: ato ou efeito de estabelecer as bases, ordenar e dispor; conformação e estrutura; associação ou instituição com objetivos específicos; planejamento e preparo. 
O DO (desenvolvimento organizacional) é uma estratégia educacional que visa mudar crenças, atitudes, valores e estrutura da empresa, de modo que elas possam adaptar-se a novos mercados, tecnologias e desafios e o próprio ritmo da mudança.

Na visão de Kegan (1971, p. 453):

O DO tem como fundamento ajudar aos membros de uma organização a remover as barreiras que impedem a liberação do seu potencial humano. De forma geral, os programas de DO podem incluir metas específicas como, por exemplo: atmosfera para solução de problemas; construção de confiança; redução de competição inapropriada e promoção da colaboração entre os membros da organização; desenvolvimento de sistema de recompensas que reconheça tanto as metas organizacionais quanto as metas individuais; incrementar o autocontrole e a auto direção dos membros da organização; entre outras.

Os primeiros estudos desenvolvidos a respeito de desenvolvimento organizacional não surgiram para cuidar da permanência do sistema organizacional e sim para aumentar o nível de satisfação dos indivíduos, tornando-os mais motivados para o trabalho e aumentando-Ihes a eficiência pessoal. De estudos ligados ao indivíduo, e ao seu desenvolvimento nas organizações, psicólogos e sociólogos entraram nas organizações para iniciarem os estudos ligados ao desenvolvimento grupal, visando conhecer as condições que levaram a melhorar seu desempenho, ao lado daqueles que causariam a desagregação grupal (PANIGHEL, 2013).

Com o passar do tempo, um novo estudo foi desenvolvido, com isso, tentou-se mudar a própria organização e não apenas os indivíduos que nela trabalhavam. O terceiro estudo foi realizado colocando a organização em um ambiente mutável, sujeito a forças que não são fáceis de controlar. Está com certeza caberia nos dias atuais devido as incertezas que vivemos. Diante disso, os estudos para desenvolver as organizações se preocupam com os problemas centrais de sobrevivência, como as estratégias que as empresas devem desenvolver para manterem-se atuantes.

Segundo Nassar (2000) a cultura organizacional se refere ao padrão compartilhado de crenças, suposições e expectativas tidas pelos membros da organização, e a sua maneira característica de perceber os artefatos da organização e o ambiente, bem como suas normas, papéis, e valores na forma como existem externamente ao indivíduo. Cultura organizacional é um reflexo da personalidade da organização, e de forma análoga, à personalidade de um indivíduo, nos permite prever atitudes e comportamentos.

A força da cultura organizacional, defendendo que a formulação das estratégias, o estilo de liderança preferido e as maneiras aceitas de se realizar tarefas, entre outras facetas importantes da vida organizacional, são realmente reflexos da cultura específica da organização em questão. (BUONO, 2002).

Culturas organizacionais mudam. Como a cultura é uma parte integrante do processo de aprendizado e experiência de um grupo, ocorrem mudanças ao 
longo do tempo, à medida que as pessoas enfrentam mudanças no ambiente externo e problemas levantando pelos esforços internos de integração.

De acordo com Fleury; Fisher (1991) a verdadeira mudança cultural é frequentemente um processo que consome tempo e dinheiro, além de ser uma experiência emocionalmente extenuante. De fato, os esforços mais bemsucedidos de mudança cultural parecem ter sido baseados em redirecionamentos incrementais e esforços para honrar o passado da empresa.

Há duas formas básicas de se efetuar uma mudança cultural na organização: fazer com que os integrantes da organização 'comprem' a ideia de uma nova configuração de crenças e valores ou, recrutando e socializando novas pessoas para dentro da organização, já as posicionando sobre estas novas crenças e valores.

De acordo com Moreira (2012, p. 31):

Na tentativa de introduzir grandes mudanças numa organização, os gerentes frequentemente começam fazendo uma avaliação e então uma tentativa de mudar as atitudes dos funcionários. Esta abordagem é consistente com o conhecimento tradicional de que as crenças e atitudes influenciam o comportamento. Como destaca uma massa significativa de pesquisas, uma das maneiras mais eficazes de se mudar crenças e valores são começando por mudanças nos comportamentos correlatos. Embora as atitudes influenciem o comportamento, é importante enfatizar que o comportamento também influencia as atitudes.

Somente por meio do diálogo e reuniões para analisar a opinião de cada colaborador é que o gerente conseguirá concluir com sua mesma equipe o processo de mudança organizacional.

Por que as empresas têm de se desenvolver? O Conceito fica mais evidente quando encaramos as instituições e as suas rotinas, o esforço é diário e contínuo para que se consiga atingir seus objetivos e cumprir suas metas, mesmo que a organização não tenha o propósito de crescer, melhorar, a simples permanência estática exige muito trabalho. É por meio deste exercício diário que constitui a essência do desenvolvimento das organizações.

O conceito corrente está ligado não a ideia de manter, mas, em geral, à ideia de melhorar, aliada à filosofia de crescer, aumentar, progredir. A meta mais ampla das empresas de negócio extravasa o lucro e se localiza na sobrevivência. Empresas nascem, crescem, se transformam, expandem-se, às vezes sofrem cisões, deterioram-se e morrem (MOREIRA, 2012).

Para Fleury; Fisher (1991) quanto mais aptas forem as empresas, maior será o tempo de duração em que começarão a dar lucros, que propiciarão empregos, serão locais onde as pessoas exercerão suas vocações. Empresa morta não tem nada disso. E a vida de um sistema empresarial só se mantém por meio de um esforço crescente, pois a incompetência elimina os piores. Esta é a razão básica da ênfase em desenvolver as organizações: a sobrevivência. 
De acordo com Paniguel (2013) o feedback ou retorno é um mecanismo importante para a qualidade de produtos e serviços de uma empresa. Ele envolve a avaliação do desempenho de alguém no trabalho. A pessoa pode dálo ou recebê-lo - faces de um mesmo processo que envolve delicadeza e tato. Feito de maneira adequada, ele pode melhorar a performance.

De acordo com Eliezer Leite que publicou no site administradores.com.br, o artigo "A Importância do feedback nas relações interpessoais" essa ferramenta é utilizada com extrema utilidade na condução das relações humanas. Eliezer informa também que as pessoas se comunicam umas com as outras e dão feedback de suas ações e atitudes constantemente, e alerta que dentro de uma organização esse é importante para a manutenção de um bom clima organizacional.

Para que um feedback se torne útil é preciso que ele seja: descritivo (que tenha a essência do tema), específico (mostrando objetividade), compatível com as necessidades do comunicador e do receptor (que atenda a cada um de maneira igualitária), dirigido (não vale carapuça, é necessário indicar claramente a quem está dirigido o feedback), solicitado (sempre estar disponível quando solicitado), oportuno (para que haja fluência no relacionamento) e esclarecido (o outro lado precisa saber exatamente que se trata de um feedback) - LEITE (2017).

O retorno adequado reforça comportamentos e desempenhos desejados para que continuem e uma das suas consequências positivas é o aumento da autoestima.

Dar e receber feedback deveriam ser práticas naturais e frequentes nas empresas, pois sempre há o que melhorar. A autoridade e competência de quem avalia e a cultura e o clima organizacional influenciam e compõem um cenário determinante para a qualidade do feedback. Quando a cultura é mais aberta e se tem um clima positivo, predispõem as pessoas a tolerarem e a aceitar as críticas. Cultura mais fechada e de clima pesado, tendem a comprometer até as avaliações positivas. (PIMENTA, 2010, p. 122).

Para Leme (2007) o feedback de desempenho é importante para uma organização operar de forma eficaz. Gerentes costumam realizar revisões anuais para todos os funcionários. No entanto, avaliações mais frequentes são importantes porque ajudam os funcionários a melhorar seu desempenho. Os gerentes também precisam dar louvor em uma base contínua, porque constrói a confiança do empregado e lealdade. Duas vias de comunicação é uma forma de trocar informações e melhorar a produtividade. Os funcionários precisam fornecer feedback para a gestão do processo de trabalho e relatar os problemas que precisam ser melhorados.

Percebe-se em uma organização a equipe que recebe feedback e a equipe que não recebe. Existem gestores que não utilizam esta ferramenta, pois acreditam não ser necessariamente importante no desempenho de sua equipe. 
Em uma organização há vários tipos de líderes, ou podemos dizer chefes. Veem-se claramente quando uma equipe tem um líder que todas as suas atitudes, sejam elas eficientes ou não, o líder está sempre por perto para classificá-las e orientá-las. Já na equipe que tem o chefe, nunca ocorrem reuniões, feedbacks instantâneos ou mesmo, conversas informais.

Pimenta (2010) informa que é necessário identificar a característica ou ato a ser elogiado. Uma única palavra ou um simples café no fim do dia contém uma energia motivacional. Declara Pimenta (2010) também que o elogio representa uma força que pode até mudar a eficácia de sua equipe. A organização ganha energia positiva que tende a ser mais produtiva. O custo é mínimo, apenas de tempo. Basta investir alguns minutos para fazer o comentário para produzir um ambiente mais propício ao trabalho em equipe e motivar todas as pessoas. Mas não se deve mudar de atitude repentinamente.

Relata Bowditch; Buono (1992, p. 46):

Uma vez que a mecanização do trabalho durante a Revolução Industrial privou os cargos de boa parte de seu significado intrínseco, as pessoas buscaram o significado em suas atividades profissionais através do relacionamento social no trabalho. Argumentava-se que a administração precisava ajudar as pessoas a satisfazerem estes desejos naturais. Se os administradores não respondessem a essas necessidades socialmente orientadas com a maior consideração e valor, via-se como prováveis consequências o desempenho deficiente no trabalho e na resistência à autoridade.

As necessidades humanas recaem em diversas categorias e variam de acordo com o estágio de desenvolvimento do indivíduo e a situação também de sua vida pessoal. As pessoas são capazes de adquirir novos motivos por meio de experiências organizacionais, o mesmo indivíduo pode demonstrar necessidades diferentes em organizações diferentes.

Os empregados tornam-se produtivamente envolvidos com a organização devido a milhares de motivos diferentes. O mesmo acontece com as equipes de trabalho que respondem de forma diferente aos estímulos que a organização disponibiliza (BOWDITCH; BUONO, 1992, p. 48).

A motivação individual para realizar uma tarefa precisa ser inferida da quantidade de esforço observável exercido na realização das tarefas. De acordo com Mendes (2011, p. 08):

A identidade pessoal e as identidades coletivas resultam, assim, da relação que um indivíduo ou um grupo mantém com o que se chama alteridade. É dessa relação com a alteridade que se depreendem numerosos comportamentos individuais que se podem observar cotidianamente.

Essa dupla relação (individual e coletiva) com a alteridade sempre existiu e invade todos os níveis (indivíduo, grupo, organização, sociedade, mundo). 
Todavia, ela toma em nossos dias uma significação e uma importância bem particulares. A falta de confiança pode gerar conflito nestas relações, pois a existência do conflito é caracterizada pela interdependência das partes; a incompatibilidade, percebida por uma delas, sobre objetivos ou comportamentos do outro e, em alguns casos, da interação que isso provoca entre elas.

As organizações são compostas de pessoas que trazem para o ambiente de trabalho todo o seu jeito de ser, sentir e viver. São motivações diferentes, habilidades e aptidões diversas, competências distintas que precisam conviver e produzir. Daí a importância de se criar um ambiente de confiança mútua com visão acurada da organização.

Nesse sentido, informa Souza (2011, p. 14-15):

Abrir espaço para a manifestação e para a expressão da personalidade, assim como para a discussão de ideias, em meio a críticas construtivas e respeitando os limites de cada pessoa são fatores a serem considerados diante da necessidade de adaptação aos novos paradigmas. Ou seja, investir e reter talentos, bem como gerir competências, visando a obtenção de resultados, a manutenção no mercado competitivo, sem perder de vista o respeito e a valorização à pessoa.

Um ponto de partida ao se debater o tema é o reconhecimento de que na empresa, as pessoas também são dotadas de necessidades, que se distinguem conforme a personalidade e que devem ser levadas em consideração, sendo esse um relevante fator para a obtenção e manutenção de uma equipe coesa, reconhecida e motivada, bem como disposta a trabalhar por melhores resultados das organizações das quais fazem parte.

No dia a dia, somos considerados agentes transformadores e sujeitos ativos no processo de construção, uma vez que o conhecimento construído na troca e na participação se constitui em grande valor estratégico para o desenvolvimento da sociedade e condição importante na qualidade de vida das pessoas.

\section{CONSIDERAÇÕES FINAIS}

Em nossa cultura de buscar sempre o culpado, enfrentamos diariamente várias situações, algumas razões e motivos dos porquês da não realização da tarefa. Ao sermos chamados para uma conversa - principalmente no campo profissional, o primeiro ato que realizamos é nos armamos de explicações, de culpados e assim por diante. Passamos mais tempo dando explicações das falhas do que dos bons resultados. A cultura que as organizações utilizam de falta de elogios contribui para a busca do culpado.

A liderança inserida na comunicação organizacional tem apenas uma função: facilitar e coordenar os esforços de indivíduos e grupos e, com isso contribuir para as realizações das metas organizacionais. A eficácia tanto da 
comunicação interpessoal quanto da comunicação organizacional determina, em grande parte, o sucesso como um todo. Algumas corporações gastam grandes somas de dinheiro do orçamento de desenvolvimento de recursos para treinar os funcionários nas habilidades de comunicação: parecer ser um dinheiro bem gasto.

Para que a organização possa assegurar que os objetivos estão sendo realizados com o melhor de capacidade do grupo, deve haver uma comunicação sólida entre a administração e os funcionários envolvidos. Inicialmente, a administração deve sempre ter suas expectativas claras. A gestão mais específica é em sua comunicação com os empregados, o que é extremamente necessária para que a organização continue a progredir. Em segundo lugar, é fundamental que a gestão seja tão transparente quanto possível com seus empregados, mantendo os empregados cientes quanto 0 que está acontecendo na organização como um todo. Quando se fala em comunicação em meio a organização, pensamos na necessidade de vender algo ou alguma ideia a outras pessoas.

É necessário comunicar o propósito e convencer as outras pessoas a comprarem. Quando os líderes comunicam uma visão de forma efetiva, para um pequeno grupo ou para a organização inteira, ela tem efeitos muito poderosos.

Num conceito mais amplo e moderno, o profissional tem que proporcionar uma comunicação clara e precisa ter decisões rápidas, visão e ação integral, iniciativa própria e informação plena do negócio da empresa.

A organização que permite o colaborador expressar suas ideias e fazer parte de todo o plano de ação, será desenvolvida e criará um time de alto desempenho. Uma vez que a comunicação entre o líder e o liderado se estabelece, todas as reações dos seguidores serão automaticamente conhecidas pelo líder. O líder tem entendido que é um elemento chave dentro da organização.

Neste sentido, o líder deve reconhecer a importância da comunicação no exercício da liderança. Para ser líder é preciso ter capacidade de agregar pessoas e conduzi-las na mesma direção, lidando com suas emoções, destacando valores e acenando com o sucesso. Este desafio exige grande domínio das técnicas de comunicação e muitos gestores não valorizam a comunicação.

O líder pode influenciar no esforço a ser mobilizado tendo em vista o caminho em busca das recompensas esperadas e que, portanto, determinarão também o nível de aceitação do líder por parte dos próprios subordinados.

É fundamental saber comunicar-se de forma clara e concisa para a sua equipe as estratégias da empresa, o que é esperado do colaborador, qual o foco da organização. Uma liderança ditatorial não tem mais espaço hoje e dia, pois é necessária a participação de todos da equipe, o diálogo, a colaboração e cocriação. É necessário permitir que as pessoas contribuam para o desenvolvimento da organização e o líder estando diretamente ligado sua 
equipe, poderá proporcionar as ferramentas necessárias para se atingir o objetivo.

\section{REFERÊNCIAS}

BENNIS, W. G. Organization development: its nature, origins and prospects. Reading, Mass: Addison-Wesley, 1969.

BERGAMINI, Cecilia Whitaker. Psicologia aplicada à administração de empresas. 3. ed., São Paulo: Atlas, 1990.

. Liderança: Administração do sentido. 2. ed., São Paulo: Atlas, 1994.

BERNARDINHO. Transformando suor em ouro. Rio de Janeiro: Sextante, 2006.

BOWDITCH, James L.; BUONO, Anthony F. Elementos de comportamento organizacional. São Paulo: Pioneira, 1992. . São Paulo: Pioneira, 2006.

BUONO, Anthony F. Elementos de comportamento organizacional. São Paulo: Pioneira, 2002.

CHIAVENATO, Idalberto. Administração nos novos tempos. 2.ed.,Rio de Janeiro: Campus, 1999.

. Introdução à teoria geral da administração. 6. ed., Rio de Janeiro: Campus, 2000.

Teoria Geral da Administração. 6. ed., rev. atual. Rio de Janeiro: Campus,2001.

.7. ed.,rev. e atual. Rio de Janeiro: Campus 2003.

ERVILHA, A.J. Limão. Liderando equipes para otimizar resultados. São Paulo: Nobel, 2008.

FLEURY, Maria Tereza Leme; FISCHER, Rosa Maria. Cultura e poder nas organizações. Rio de Janeiro: Atlas, 1991.

GAUDÊNCIO, Paulo. Superdicas para se tornar um verdadeiro líder. São Paulo: Saraiva, 2007.

GENELOT, D. Manager dans la complexité: reflexions à l'usage des dirigents. 3. ed., Paris: Insep Consulting, 2001. 
GESSNER, Graciele. A boa comunicação. Disponível em:

<http://www.artigos.com/artigos/sociais/administracao/comunicacao-

1511/artigo/\#.UtGbytJDs8o> Acesso em: 12 de dez. de 2017.

GIL, Antônio Carlos. Como elaborar um projeto de pesquisa. 4. ed.,São

Paulo: Atlas, 2002.

HOUSE, R. J. A Path Goal Theory of Leader Effectiveness.Administrative Science. vol. 16, Philadelphia: Quarterly, 1971.

JESUS, Antonio. Estilos de Comunicação em liderança. Disponível em: $<$ http://www.portal-gestao.com/gestao/lideranca/item/2554-estilos-decomunica\%C3\%A7\%C3\%A3o-em-lideran\%C3\%A7a.html> Acesso em 02 de nov. de 2017.

LACOMBE, Francisco; HEILBORN, Gilberto. Administração: princípios e tendências. São Paulo: Saraiva, 2008.

LAPIERRE, Laurent. (trad.) Cecília W. Bergamini; Roberto Coda. Revista de Administração de Empresas. Imaginário, administração e liderança. Vol. 29 n.4 São Paulo Out./Dez. 1989.

LEITE, Eliezer. A Importância do feedback nas relações interpessoais. Disponível em: $<$ http://www.administradores.com.br/artigos/administracao-enegocios/a-importancia-do-feedback-nas-relacoes-interpessoais/21459/> Acesso em 30 de dez. de 2017.

LEME, R. Feedback para resultados na gestão por competências pela avaliação 360: guia prático para gestores do "dar e receber": feedback e a transformação em resultados. Rio de Janeiro: Qualitymark, 2007.

MASLOW, Abraham H. A theory of Human Motivation: Psychologist Review. Nova York: Harper \& Row, 1943.

MENDES, Denise Figueiró. Recursos humanos - coletânea de artigos: A confiança nas relações entre gestores e colaboradores: fator determinante para melhorar a eficácia organizacional, ECXCard, Belo Horizonte, 2011.

MORAN, José Manuel. Mudanças na comunicação pessoal. São Paulo: Paulinas, 1998.

MOREIRA, Magali André. (2006) O processo de comunicação e elementos facilitadores para o gestor. Monografia - especialista em Gestão Estratégica, 92p. Universidade Candido Mendes - AVM Faculdade integrada. Rio de Janeiro,2006.

MOREIRA, Márcia Maria da Silva. (2012). Cultura organizacional. Monografia-especialista em Gestão de RH, 57p. Universidade Candido Mendes - AVM Faculdade integrada. Rio de Janeiro, 2012.

NASSAR, Paulo. História e cultura organizacional. In: Revista comunicação empresarial - n. 36, São Paulo, 2000. 
PANIGHEL, Ignez. O que é o feedback no ambiente organizacional? Disponível em: $<$ http://www.jfpr.jus.br/arquivos/office/6beb46ad112df25d2471b4ee59b6ee97.p df> Acesso em 17 de dez. de 2017.

PENTEADO, José Roberto Whitaker. A técnica da comunicação humana. 12. ed., São Paulo: Pioneira, 1993.

PIMENTA, Maria Alzira. Comunicação Empresarial. Campinas: Alínea, 2000. . Comunicação empresarial 17. ed., São Paulo: Alinea, 2010.

KEGAN, D. L. Organizational development: description, issues and some research results. The Academy of Management Journal. v. 14. n. 4, 1971.

KOTTER, John. Organizacional dynamics: diagnosis and intervention. Pearson educations: US, 1978.

RIBEIRO, João. Manual técnico do formando: comportamento organizacional. Portugal: EduWeb, 2008.

RUGGIERO, Alberto Pirró. Qualidade da comunicação interna. Disponível em: http://www.rh.com.br. Acesso em: 28 de nov. de 2017.

SCANLAN, Burt K. Princípios de administração e comportamento organizacional. São Paulo: Atlas, 1979.

SILVA, Walmir Rufino da; RODRIGUES, Cláudia Medianeira Cruz. Motivação nas Organizações. São Paulo: Altas, 2007.

SOUZA, Élida. Recursos humanos - coletânea de artigos: A importância do feedback nas organizações, ECX Card, Belo Horizonte, 2011.

SPECTOR, P. E. Psicologia nas Organizações. São Paulo: Saraiva, 2002.

STONER, J. A. F.; FREEMAN, R. E. Administração. 5. ed., Rio de Janeiro: LTC, 1999.

SUGO, Alberto. Jayr Figueiredo Oliveira e Robson Marinho (Org.). Liderança: Uma questão de competência. São Paulo: Saraiva, 2006.

THAYER, L. O. Comunicação: fundamentos e sistemas na organização, na administração, nas relações interpessoais. São Paulo: Atlas. 1972.

URIS, Auren. Liderança. São Paulo: Ibrasa, 1972.

VERGARA, Sylvia Constant. Gestão de Pessoas. 4. ed., São Paulo: Atlas, 1999. 
Recebido: 03 de setembro de 2018. Publicado: 20 de setembro de 2018.

Correspondência: Rosineia Oliveira dos Santos. E-mail: olisanta@gmail.com

Conflito de Interesses: os autores declararam não haver conflito de interesses.

(C) This is an Open Access article distributed under the terms of the Creative Commons Attribution License, which permits unrestricted use, distribution, and reproduction in any medium, provided the original work is properly cited 